\title{
Correction to: Debt and Private Investment: Does the EU Suffer from a Debt Overhang?
}

\author{
Willem Vanlaer ${ }^{1} \cdot$ Mattia Picarelli ${ }^{2} \cdot$ Wim Marneffe ${ }^{1}$ \\ Published online: 25 June 2021 \\ (C) Springer Science+Business Media, LLC, part of Springer Nature 2021
}

\section{Correction to: Open Economies Review https://doi.org/10.1007/s11079-021-09621-x}

The original version of this article unfortunately contained a mistake. Below Acknowledgements was missing.

Acknowledgements We thank Samanta Bielen, Nicola Borri, Angela Capolongo, Alessandra Donini, Guido Traficante, Lorenzo Ricci, and two anonymous reviewers for their constructive comments on an earlier draft of this manuscript. Sylvia Baudet von Gersdorff provided excellent editorial support. The views expressed in this paper are solely the responsibility of the authors and should not be interpreted as representing the views of the European Stability Mechanism.

The original article has been corrected.

Publisher's Note Springer Nature remains neutral with regard to jurisdictional claims in published maps and institutional affiliations.

The online version of the original article can be found at https://doi.org/10.1007/s11079-021-09621-x

Willem Vanlaer

willem.vanlaer@uhasselt.be

1 Hasselt University, Faculty of Applied Economics, Martelarenlaan 42, BE-3500 Hasselt, Belgium

2 European Stability Mechanism, 6a Circuit de La Foire Internationale, L-1347 Luxembourg City, Luxembourg 